\title{
The Effect of Import and Export of Aluminum Based on Sino-US Trade Friction
}

\author{
Qin Keqi, Ji Xuewen \\ School of business, Tianjin University of Finance and Economics, Tianjin 300222 \\ Keywords: Sino-U.S. Trade Friction Shanxi Province Aluminum Import and Export
}

Abstract: Shanxi is famous for its rich mineral resources. Most people know that Shanxi has abundant coal minerals, but they don't know that Shanxi also has abundant aluminum minerals. Aluminum is an important industrial raw material, widely used in high-speed railway, astronomy, automobile and other industries. Aluminum mine is a resource cherished by China, the United States and other countries. They are all concerned about aluminum exploration, reserves, exports and imports. The trade war between China and the United States will affect the two countries and the world's aluminum market.

\section{The Trade War}

A trade war refers to two or more states rising or creating tariffs or other trade barriers on each other in retaliation for other trade barriers. Increased protection causes both nations' output compositions to move towards their autarky position. What did America do to restrain China?

\subsection{What did America do to restrain China}

\subsubsection{Section 301}

According to the Ministry of Commerce of the People's Republic of China Trade Remedy and Investigation Bureau May 5th 2011, America's 1974 Trade Reform Act Section 301 authorized U.S. trade representative (USTR) and the President appeal or decide on foreign governments investigate the unreasonable or unfair trade practices, and to impose sanctions, hence the name 301 survey. The law has been amended several times and was recently amended to be the comprehensive trade and competition act of 1988. The 301 surveys are divided into three categories, namely for foreign government unreasonable or unfair trade practices generally 301 investigations, lack of protection of intellectual property rights for foreign government special 301 investigations and for key national unreasonable or unfair trade practices of super 301 survey. Among them, the super 301 is a "temporary" provision requiring special legislative authorization, which took effect only between 1989 and 1990 and 1994-1997.

\subsubsection{Other policies issued by the White House}

As President Trump claimed to "Make America great again” by driving manufacture industry back to mainland America, the White House issued a series of policies to restrict the import of steel 
and aluminum, as these two ingredients are the most fundamental ones for other industries like car industry and astronomy industry.

\subsubsection{Main products U.S. levy tax from China}

According to Net-Easy news, the main territories that America levy tax on China are high performance medical devices, bio-pharmaceutical, new material, agricultural machinery and equipment, industrial robot, new generation of information technology, new-energy car, aviation product, high-speed rail equipment. 0

\subsubsection{Why aluminum}

Aluminum profile is the best material for light weight of high-speed rail. The density of aluminum alloy is about one third of the density of steel, and the alloy with certain elements has higher strength than steel alloy. Therefore, while the strength rigidity meets the safety requirements of the high-speed railway carriage, the use of aluminum alloy can greatly reduce the self-weight of high-speed train carriages. Generally speaking, the aluminum alloy used in a high-speed railway carriage is about 10 tons, and the weight of the whole body is $30 \%$ to $50 \%$ less than that of all steel ${ }^{[1]}$.

\subsection{What did China do to fight back U.S}

\subsubsection{Main products that China stopped tax free policies from U.S.}

According to Net-Easy news, the main products that China stopped tax free policies of import goods from America are aluminum scrap, pork, fresh fruit, dry fruit, nut, denatured ethanol, American ginseng and seamless steel tube.

\subsubsection{The influence of restrain policies}

The ban on U.S. aluminum scrap imports will increase the cost of domestic aluminum production to a certain extent. As early as when the trade war between China and the US broke out, due to the difficulty of finding new sources for replacement of imported aluminum scrap, it is still necessary to use part of the U.S. aluminum scrap processing methods to meet the demand for export orders. At the same time, because there is not enough waste supply for domestic sales, the recycled aluminum companies that mainly use imported aluminum scrap have significantly increased the proportion of export orders in April, and have also been forced to use part of the U.S. aluminum scrap.

\section{Aluminum}

Aluminum or aluminum is a chemical element with symbol $\mathrm{Al}$ and atomic number 13 . It is a silvery-white, soft, nonmagnetic and ductile metal in the boron group. By mass, aluminum makes up about $8 \%$ of the Earth's crust, it is the third most abundant element after oxygen and silicon and the most abundant metal in the crust, though it is less common in the mantle below. The chief ore of aluminum is bauxite. Aluminum metal is so chemically reactive that native specimens are rare and limited to extreme reducing environments. Instead, it is found combined in over 270 different minerals. 


\subsection{Aluminum Ore}

\subsubsection{The distribution of Aluminum ore in the world}

By the global bauxite reserves of about 28 billion tons in 2015, mainly in Guinea, Jamaica, Australia, Brazil, Vietnam and other countries. Chinese bauxite reserves are of 830 million tons, accounted for less than $3 \%$ of the reserves in the world.

From 2007 to 2015, the global production of bauxite increased rapidly. Except for the sharp decline in output caused by the global financial crisis in 2009 and the bauxite export ban in Indonesia in 2014, the growth rate in other years was at a relatively high level, with an average annual growth rate of 9 years. The rate is $4.88 \%$. The output of bauxite in the world reached 272 million tons in $2015^{[2]}$. The output from high to low is Australia, China, Brazil, India, Guinea, Jamaica, and Russia and so on.0

\subsubsection{The distribution of Aluminum ore in China}

The quality of bauxite in China is relatively poor. More than $98 \%$ of it is a diaspore-type bauxite mine with difficult processing and high energy consumption, and there are not many deposits suitable for open mining, accounting for only 34\%. The mines are mainly distributed in Guangxi, Henan, Shanxi, and Guizhou. The total reserves account for $91.17 \%$ of the country's total reserves.

\subsubsection{The distribution of Aluminum ore in Shanxi}

Xing County Bauxite Mining Area - Xingxian, Linxian, Jixian. The mining area belongs to the Hedong mineralization basin in Shanxi Province. Because the fault depression is not known, only the Dongpo ore belt is currently known. The Dongpo ore belt is 210 kilometers long and 10-30 kilometers wide, including 19 large-scale and medium-sized bauxite deposits in Baode-Xing County Linxian Liulin Zhongyang.

Among them, there are about 7 deposits on the surface of the bauxite concentration area from north to south, namely Baode Tianqiao, Haojia Tower, and Ditch Gully, Weijiatan, Huanghuitou, Hejiabangtai, and Xingjia County. Jiazhuang; retains more than 100 million tons of resources.

Among them, there are 17 deposits on the table, namely Du Village, Chaichang, Xiangwang, Shigongxi, Xiabao, Shigong, Lingshangbei-Bujiayu, Kezi Mining Section, Kezi Mining Area, and Masonry-Gui in Xiaoyi. At the end of the Russian and West Rivers, there are loud and clear meanings at the intersection, Houwu City, Nanling Shang, Pang Zixuan, Bi Jiazhang, and Zhao Jiaxuan.

Intersection - Bauxite Bauxite Area - Luliang City, Jinzhong City, Linfen City, Shanxi Province. The Luliang bauxite mining area in Shanxi Province is located on the eastern edge of the central Hedong coalfield, and the Lvliang block of Luliang-Taihang block is located in the northern part of the Shiyizhongyang diamond complex syncline. The thickness of bauxite in the mining area is generally thin at the center of the north and south, and the large thickness of the bauxite is $4.06 \mathrm{~m}$, the smaller thickness is $0.81 \mathrm{~m}$, and the average thickness is $1.51 \mathrm{~m}$.

The main chemical composition of ore is Al2O3, SiO2, Fe2O3, TiO2, and the chemical composition of the ore in the whole area is: $\mathrm{Al} 203$ is $44.32 \%-78.91 \%$, average $67.42 \%$; $\mathrm{SiO} 2$ is $1.57 \%-22.10 \%$, average $9.11 \%$. 


\subsection{Aluminum Applications}

\subsubsection{Aluminum alloys}

Aluminum alloys are alloys in which aluminum (Al) is the predominant metal. The typical alloying elements are copper, magnesium, manganese, silicon, tin and zinc. There are two principal classifications, namely casting alloys and wrought alloys, both of which are further subdivided into the categories heat-treatable and non-heat-treatable. About $85 \%$ of aluminum is used for wrought products, for example rolled plate, foils and extrusions. Cast aluminum alloys yield cost-effective products due to the low melting point, although they generally have lower tensile strengths than wrought alloys. The most important cast aluminum alloy system is $\mathrm{Al}-\mathrm{Si}$, where the high levels of silicon (4.0-13\%) contribute to give good casting characteristics. Aluminum alloys are widely used in engineering structures and components where light weight or corrosion resistance is required ${ }^{[3]}$.

\subsubsection{The application of Aluminum alloys}

In general, stiffer and lighter designs can be achieved with Aluminum alloy than is feasible with steels. For instance, consider the bending of a thin-walled tube: the second moment of area is inversely related to the stress in the tube wall, i.e. stresses are lower for larger values. The second moment of area is proportional to the cube of the radius times the wall thickness, thus increasing the radius (and weight) by $26 \%$ will lead to a halving of the wall stress. For this reason, bicycle frames made of aluminum alloys make use of larger tube diameters than steel or titanium in order to yield the desired stiffness and strength. In automotive engineering, cars made of aluminum alloys employ space frames made of extruded profiles to ensure rigidity. This represents a radical change from the common approach for current steel car design, which depend on the body shells for stiffness, known as unibody design.

\section{The impact of the Trade War on the import and export of aluminum in Shanxi}

\subsection{The aluminum import and export in the world}

Scrap Aluminum is the 303rd most traded product and the 820th most complex product according to the Product Complexity Index (PCI). ${ }^{0}$

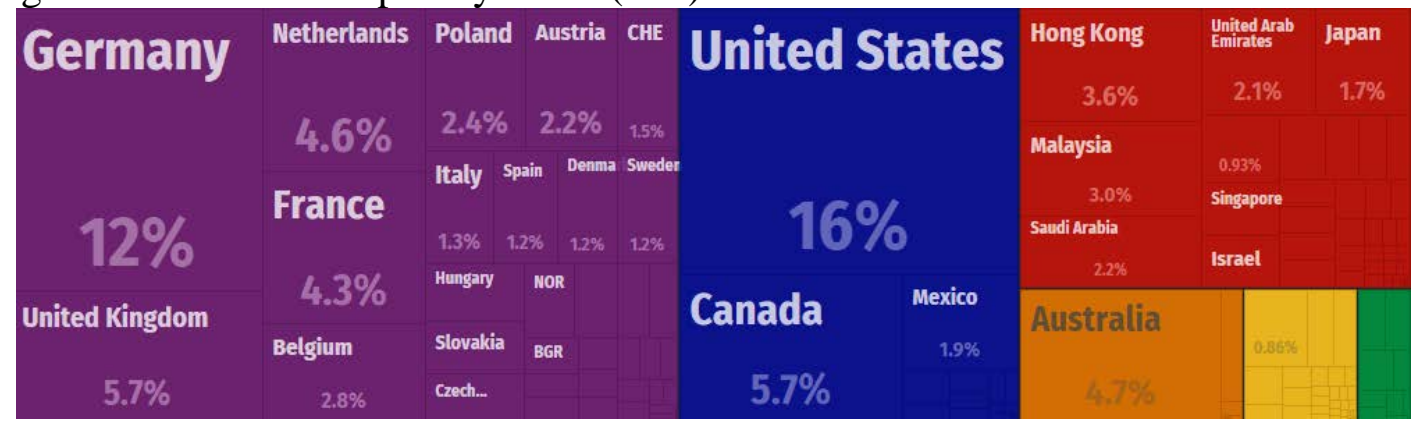

The top exporters of Scrap Aluminum are the United States $(\$ 1.83 \mathrm{~B})$, Germany $(\$ 1.43 \mathrm{~B})$, Canada $(\$ 668 \mathrm{M})$, the United Kingdom $(\$ 666 \mathrm{M})$ and Australia $(\$ 550 \mathrm{M})$. The top importers are China (\$2.7B), India (\$1.24B), Germany (\$1.03B), South Korea (\$836M) and the United States (\$780M).

This treemap shows the share of countries that export Scrap Aluminum. The total amount is: \$11.7B. The data comes from OEC: The Observatory of the Economic Complexity. This treemap shows the share of countries that import Scrap Aluminum. The total amount is: \$11.7B. 


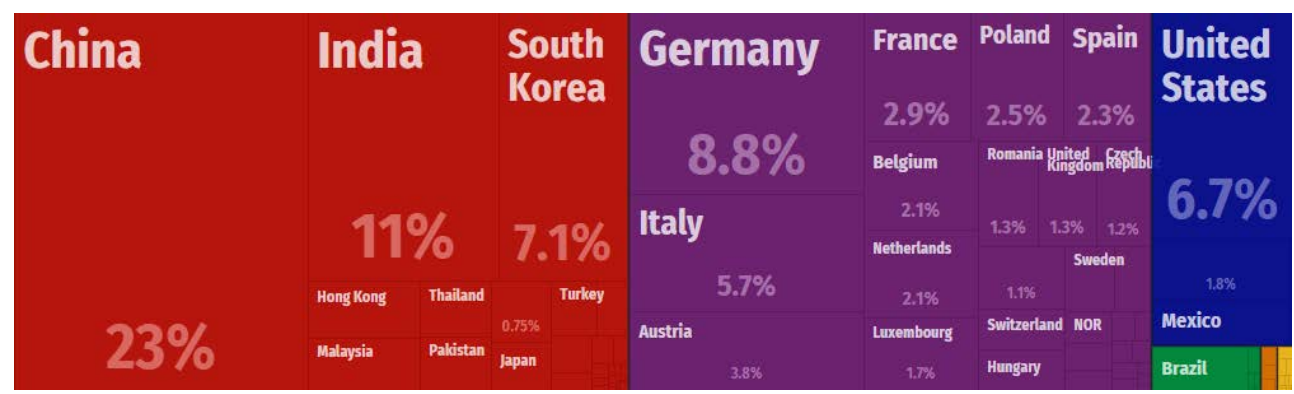

So we can see from the chart that the United States is the largest exporter of Scrap Aluminum and China is the largest importer of Scrap Aluminum. China's policies of cut the tax diminishing policy of scrap aluminum from America would infect the related enterprises in both countries.

\subsection{The aluminum import and export of China}

In China, a large proportion of the demand for bauxite needs to be met annually. In 2015, the import volume was 55.82 million tons, accounting for $46.20 \%$ of the total supply of bauxite in China (domestic production and import). Before 2014, $80 \%$ to $90 \%$ of the supply of our country imported from Indonesia, high import concentration made our bauxite imports easily affected by Indonesia's trade policy. In 2012 and 2014, Indonesia bauxite was under export restrictions, bauxite imports obvious atrophy in our country. As the ban of Indonesia bauxite export continue to last, Australia became largest bauxite exporter to our country, moreover, China will also import from Guinea, Malaysia, India, Brazil, Ghana and other countries ${ }^{[4]}$.

In terms of cost, imported or domestic mines have their advantages and disadvantages. Due to the differences in freight and grade, the CIF of imported ore is generally higher than that of domestic mines. In 2015, the average price of imported ores was RMB 31.98/t, higher than domestic mines. Considering that most of the bauxite used by domestic alumina companies is self-produced ore, the cost is the cost of mining (according to the aluminum article "High-quality aluminum mineral resources, Guangxi or become a national low-cost alumina base", the mining cost is about 180 yuan/ $t$ ), the price of imported ore is more disadvantageous.

However, domestic mines are mostly low-grade diaspore-type bauxite mines. The energy consumption of alumina production is higher than that of imported bauxite mines. According to the regulations of the Aluminum Industry Specification, the Bayer process for imported mines can be used for energy consumption. It should be less than $500 \mathrm{~kg}$ standard coal per ton of alumina, and other processes suitable for domestic mines should consume less than $800 \mathrm{~kg}$ of standard coal per ton of alumina, a production process of 1 ton of alumina in accordance with 2 tons of bauxite, domestic ore The energy consumption is about $150 \mathrm{~kg}$ higher than that of imported coal. According to the 2015 standard of RMB 524.85 per ton of standard coal, the cost will be RMB 78.73 per ton.

At present, the static mining life of domestic bauxite is only 14 years, which lags far behind the global 102 years. In the future, China is likely to face the predicament of domestic resource shortage, and the bauxite supply gap formed will be more dependent on imports. Imports of bauxite and foreign dependence are likely to increase substantially. However, judging from the global bauxite reserve distribution structure and the current production status, the future output of bauxite giants such as Guinea, Brazil, and Vietnam still has a large room for growth. The future global bauxite mines will still be in a relatively loose state of supply. And the source of supply will be more decentralized, and our country is less likely to be subject to human resources. ${ }^{0}$

\subsection{The aluminum import and export of Shanxi}

Shanxi is the largest aluminum reserve area of China. Both Aluminum Corporation of China 
Limited and State Power Investment Corporation Limited settled numerous subsidiaries in Shanxi province for the convenient ingredients for both steel and aluminum, as they are important industrial ingredients as we analyzed above in America part. However, the aluminum ore in Shanxi is not allowed for export out of two reasons. One is that the nation would preserve its own natural reserves out of national safety, the other is the environmental pollution should be cut and as "Beautiful scenery is the gold and silver mines", Shanxi should turn its orientation of develop tourism rather than coal mine or aluminum mine, so the produce under the suppress cannot meet our own need, let alone export to other countries.

The export of aluminum in Shanxi is not direct, however, as the shell of Chinese high-speed rail is aluminum alloy, the impact of America levying tax on China's high-speed rail would infect Shanxi's aluminum produce indirectly.

\section{Conclusions}

Through the analysis above, trade war between China and the U.S. won't do any good for both nor to the world. As an important mine reserve area and an industrial province, trade war wouldn't benefit Shanxi neither.

Up to May 20, 2018, according to www.gov.com, Chairman Xi Jinping's special envoy, member of the Political Bureau of the CPC Central Committee, vice premier of the State Council, and Chinese leader Liu He of the China-U.S. Comprehensive Economic Dialogue received an interview from the media on the morning of the 19th. He said that the biggest achievement of the Sino-U.S. economic and trade consultations was that the two sides reached a consensus, did not fight a trade war, and stopped levying tariffs on each other.

\section{References}

[1] "What is trade war? definition and meaning". Business Dictionary.com. Retrieved 2017-08-15.

[2] DIANE P. WOOD , Deputy Assistant Attorney General, Antitrust Division, U.S. Department of Justice. Friday, March 24, 1995. Antitrust: A Remedy For Trade Barriers?. The United States Department of Justice.

[3] Statement from President Donald J. Trump on Additional Proposed Section 301 Remedies.

[4] Presidential Proclamation Adjusting Imports of Aluminum into the United States. https://www.whitehouse.gov/presidential-actions/presidential-proclamation-adjusting-imports-aluminum-united-states3/ 